\title{
The belief in health in the adoption of COVID-19 prevention and control measures
}

\author{
A crença em saúde na adoção de medidas de prevenção e controle da COVID-19
}

La creencia en salud en la adopción de medidas de prevención y control de la COVID-19

Khelyane Mesquita de Carvalho' ORCID: 0000-0003-4270-3890

Cynthia Roberta Dias Torres Silva' ORCID: 0000-0002-3331-2719

Sarah Giulia Bandeira Felipe ORCID: 0000-0001-5997-190X

Marcia Teles de Oliveira Gouveia' ORCID: 0000-0002-2401-4947

'Universidade Federal do Piauí. Teresina, Piauí, Brazil.

How to cite this article:

Carvalho KM, Silva CRDT, Felipe SGB, Gouveia MTO. The belief in health in the adoption of COVID-19 prevention and control measures.

Rev Bras Enferm. 2021;74(Suppl 1):e20200576. doi: http://dx.doi.org/10.1590/0034-7167-2020-0576

Corresponding author:

Khelyane Mesquita de Carvalho

E-mail: khelyanemc@gmail.com

EDITOR IN CHIEF: Dulce Barbosa ASSOCIATE EDITOR: Hugo Fernandes

Submission: 06-02-2020

Approval: 11-01-2020

\section{ABSTRACT}

Objective: Reflect, in the light of the Health Belief Model, on the adoption of behavioral measures in the context of COVID-19. Methods: Theoretical-reflective essay, based on the Health Belief Model, to reflect on adherence to preventive behaviors in the pandemic of COVID-19. Results: Adherence to preventive behaviors is strongly influenced by socioeconomic, territorial, political and individual factors in the face of critical health situations. In addition, the spread of false news modulates the thinking and execution of behavioral actions in the population. Final Considerations: It is necessary to understand the importance of health communication processes and the use of tools aimed at responsible human behavior and engaged in the adoption of a preventive posture.

Descriptors: Health Behavior; Culture; Coronavirus Infections; Pandemics; Disease Prevention.

\section{RESUMO}

Objetivo: Refletir, à luz do Modelo de Crença em Saúde, sobre a adoção de medidas comportamentais no contexto da COVID-19. Métodos: Ensaio teórico-reflexivo, embasado no Modelo de Crença em Saúde, para refletir sobre a adesão a comportamentos preventivos na pandemia de COVID-19. Resultados: A adesão a comportamentos preventivos é fortemente influenciada por fatores socioeconômicos, territoriais, políticos e individuais ante situações críticas de saúde. Além disso, a propagação de falsas notícias modula o pensamento e a execução de ações comportamentais na população. Considerações Finais: Faz-se necessária a compreensão da importância de processos de comunicação em saúde e utilização de ferramentas direcionadas ao comportamento humano responsável e engajado na adoção de uma postura preventiva.

Descritores: Comportamento de Saúde; Cultura; Infecções por Coronavírus; Pandemias; Prevenção de Doenças.

\section{RESUMEN}

Objetivo: Reflejar, a la luz del Modelo de Creencia en Salud, sobre la adopción de medidas comportamentales en el contexto de la COVID-19. Métodos: Ensayo teórico-reflexivo, basado en el Modelo de Creencia en Salud, para reflejar sobre la adhesión a comportamientos preventivos en la pandemia de COVID-19. Resultados: La adhesión a comportamientos preventivos es altamente influenciada por factores socioeconómicos, territoriales, políticos e individuales ante situaciones críticas de salud. Además, la propagación de falsas noticias modula el pensamiento y la ejecución de acciones comportamentales en la población. Consideraciones Finales: Se hace necesaria la comprensión de la importancia de procesos de comunicación en salud y utilización de herramientas apuntadas al comportamiento humano responsable y comprometida en la adopción de una postura preventiva.

Descriptores: Comportamiento de salud; Cultura; Infecciones por Coronavirus; Pandemias; Prevención de Enfermedades. 


\section{INTRODUCTION}

In the last few months, the public health emergency caused by COVID-19 has triggered unease and multiple questions about the real magnitude of social commitment to health. If occasionally the individual commitment to collective health was questioned under the ethical and moral sphere, today it is a prominent factor in the scientific community and among the population.

The disease was initially identified in Wuhan province, China, in December 2019; and, since then, it has been propagated to several countries, including Brazil. The causative etiologic agent is the new Sars-CoV-2 coronavirus, and its transmission occurs from person to person, mainly through direct contact or through droplets disseminated by the cough or sneeze of an infected person, causing symptoms ranging from the flu to severe pneumonia ${ }^{(1)}$.

Worldwide, 23,518,343 cases and 810,492 deaths from COVID-19 were confirmed by August 24, 2020. In Brazil, the situation worsens in a similar way: in the same period, the number of reported cases reaches $3,622,861$, with 115,309 deaths. Factors such as the high speed of dissemination, lethality, virulence and insufficient scientific knowledge contribute to the increase in the number of cases and show the need to adopt preventive measures ${ }^{(2-3)}$.

In a broader view, the social determination of the healthdisease process of the current pandemic is strongly marked by the influence of numerous behavioral factors. So far, social norms to contain the infection, such as the adoption of hygiene measures and social isolation have been the most important preventive recommendations to reduce the rate of virus transmission ${ }^{(2)}$.

Behavioral aspects and population beliefs in the face of the COVID-19 pandemic have been the object of study in order to consolidate knowledge of the influence of the inadequate belief system and enhance the development of strategies that can foster assertive practices in controlling the disease ${ }^{(4)}$. We say this because mistaken behaviors about forms of transmission, treatment and prevention are common, and they are often based on information conveyed by unofficial sources that constitute evident processes of disinformation, such as fake news. These contents, in turn, can encourage the population to consume inadequate medications, intensify actions that are too exaggerated (stock up on goods) or even react to the disease by inadvertently spreading the virus ${ }^{(5)}$.

Since traditional and vertical concepts still establish barriers for defragmented health care and surveillance actions ${ }^{(6)}$, Since traditional and vertical concepts still establish barriers for defragmented health care and surveillance actions $s^{(7)}$.

\section{OBJECTIVE}

To reflect, in the light of the Health Belief Model, on the adoption of behavioral measures to reduce the spread of COVID-19.

\section{METHODS}

This is a theoretical-reflective essay, based on the Health Belief Model, to reflect on adherence to preventive behaviors in the pandemic of COVID-19. The articles used for the justification were accessed through the following databases: Latin American and Caribbean Literature in Health Sciences (LILACS), consulted by the Virtual Health Library (VHL), Medical Literature Analysis and Retrieval System Online (MEDLINE), via PubMed. Among the descriptors and keywords used in the search, the following stand out: "Health Behavior", "Culture", "Coronavirus Infections", "Pandemics", and "Disease Prevention".

\section{COVID-19 AND THE BELIEF IN HEALTH MODEL}

When pondering beliefs, fears and myths in the prevention and control of COVID-19, it appears that the adoption of positive health behaviors permeates thoughts, perceptions, expectations, feelings, habits and risk behaviors ${ }^{(4)}$. Therefore, reflecting on these issues, it is observed that preventive actions in this context only modify the behavior of people who believe in the benefits of such changes, that is, that their actions are able to reduce their susceptibility, seriousness of virulence and consequently the risk of death.

Although the rules of social restriction and isolation adopted internationally allow empirical analysis to mitigate the spread of the virus, it is worth remembering that common sense, built and propagated by the false belief that the pandemic started in Wuhan, China, would not spread worldwide, interfered especially in the resistance in not adhering to measures of containment and social alert ${ }^{(8)}$.

This reality can be discussed based on the Theoretical Model of Health Belief, which seeks to explain and predict human behavior in the health-disease process, based on the assumption that, for the person to put into practice preventive behaviors, he needs to believe that he is personally susceptible to a health problem and that it can have serious consequences on some component of your life.

The Health Belief Model was developed by a group of social psychologists from the American public health service in the 1950s, with the aim of understanding people's resistance to accepting preventive health measures or tests to detect asymptomatic diseases early. As a predictor of preventive behavior, the model is basically composed of four dimensions: susceptibility, severity, benefits and barriers. These add to the subjective perceptions of each person/family and interfere in the decision-making process ${ }^{(7)}$.

The components underlying the health belief model are derived from Lewin's force field theory ${ }^{(7)}$, that seeks to examine human behavior and individual motivation in the face of any new fact. Thus, the model works by proposing dimensions that intend to explain decision making in relation to recommended actions in the field of health forces. In other words, he studies behavior in terms of perceived threats, whether or not they emerge from the perception and motivation of each one.

The fundamentals of the model include individual perception, which will be influenced by modifying factors for the action to occur. Each person attributes a value that leads him to adopt a behavior (be it favorable or unfavorable). In this way, beliefs function as cognitive mediators, that is, they determine the perceptions that will lead to action.

From a theoretical point of view, it is argued that whether a person adopts medical recommendations in relation to a particular disease depends or not on his perception of the level of personal susceptibility, the degree of severity of its consequences, the 
potential benefits to be achieved and finally, physical, psychological, financial barriers, including the cost to initiate or maintain the desired behavior.

The capacity for reflective self-awareness actively regulates human behavior, influencing attitudes and competencies in the search for health. In this regard, the individual perception of risk associated with the disease emerges as a determinant of adherence to preventive behaviors ${ }^{(6)}$ and is an essential component of theories of behavior change in health, such as the Health Belief Model.

It should be noted that health behavior depends on the different types of risk perceptions (deliberative, affective and experiential) and the accuracy of such perceptions, varying according to social aspects (such as gender, age, education and place of residence) and the set of social beliefs. In this sense, a study carried out in Ceará aiming to identify behavioral aspects and the beliefs of the population in the face of the COVID-19 pandemic revealed that men, people with low education, elderly people over 80 years old and those living in cities in the interior of the state are more vulnerable to coronavirus infection due to the thought of invulnerability to the disease, local behaviors and access to financial resources ${ }^{(5)}$.

Within singular contexts, there is a tendency to underestimate risks of experiencing some misfortune - for example, contracting COVID-19. This routine thinking does not only interfere in times of pandemic, but it continuously presents itself as a determining factor for inappropriate behaviors, such as the habit of driving under the influence of alcohol.

On the one hand, the optimistic perception, related to the false familiarity with the new coronavirus, results in low adherence to prevention behaviors; on the other hand, the exaggerated perception about the risk of contracting the disease, associated with the pessimistic bias, can have the opposite effect, generating panic or even stigmatization and aggression against social groups associated in some way with the disease ${ }^{(6) .}$

In a practical way, the real belief of contamination is strongly linked to the perception of general health itself, based on what the person asks: What are the chances of being contaminated? Regarding perceived severity, it is a personal belief about how the person would suffer the disease process and the intensity of the symptoms (eg, "If I caught coronavirus, would I get the severe form? mechanical fan?"). The principle of perceived benefits is related to the reality between modifying behavior and preventing infection (eg, "If I wear a mask, if I stay at home, do I avoid getting the disease?")

The principle related to perceived barriers seeks to understand the difficulties of respecting the protection rules and instructions and avoiding infection by coronavirus (eg, "Can just one person at home do the shopping instead of two or three help in prevention?"). In addition to these dimensions, stimuli that trigger the decision-making process are part of the model, such as experienced symptoms and external influence from friends, family and the means of communication.

It is reinforced that people receive motivations for actions that are in the force field, with positive and negative attractions, and these motivations dynamically help to define the socio-behavioral determinants of the health-disease process. In the case of the COVID 19 pandemic, it is emphasized that, even believing in the severity of the infection, erroneous information can mitigate preventive actions, generating cognitive dissonance, that is, inconsistency between what is believed and what is done.

Thus, prevention behaviors are essential and depend on the effective communication of risk perception, expected results and belief in self-efficacy. This reality can be exemplified by actions developed in Germany and New Zealand, which provided adequate epidemiological information and operationalized the dissemination of concrete information for the prevention and management of public health crises $^{(2)}$.

Hence, it can be seen that differences in resources, governments and laws have a strong impact on the configuration of the epidemic curve in different socioeconomic scenarios. In addition, individual characteristics, beliefs and cultural behaviors interfere with the adoption of protective measures and contribute to a greater severity of negative health outcomes. This shows the importance of these government actions for the adoption of a preventive posture ${ }^{(9)}$.

In the current context, the recommendations adopted are centered on a single premise: it is a highly virulent infection, which requires the adoption of new habits in a short period of time. Throughout the world, we observed that the concrete belief in the threat of life, caused by the number of deaths related to COVID-19, intensified the positive behaviors in view of the understanding of the health-disease process, varying according to the multi-determined individual condition, and this corroborates the premise that the real perception of risk leads to the adoption of preventive behaviors.

In the United Kingdom, non-pharmacological measures aimed at suppressing the spread of the virus, such as social detachment and hygiene measures, were introduced a priori on a voluntary basis, without government imposition. The evidence is found in a survey carried out in the country to examine the risk perceptions and behavioral responses of the adult population during the initial phase of the COVID-19 epidemic: it was shown that, of the 2,108 respondents, $77.4 \%$ had a perception risk of the disease and reported being concerned about COVID-19. In addition, 94.2\% of respondents reported taking at least one preventive measure; and of these, $56.5 \%$ said they adhere to social isolation ${ }^{(10)}$.

From the perspective of social isolation, Brazil has levels below that recommended by specialists, reaching an average of $41.7 \%$. The values vary according to each region of the country: Amapá, for example, is the state with the highest index of social isolation (55.8\%), while the state of Goiás has the worst index (35.9\%). These divergences are explained by issues related both to people's own perception of their potential to be contaminated with the disease and to scepticism in the real effectiveness of the measure. Aspects such as income, education, sex, age also contribute to the low rates of adherence to social isolation ${ }^{(11)}$.

When considering stimuli and uniqueness of social contexts, the health communication process highlights the need for educational interventions, elaborated with scientific theoretical basis articulated to cognitive, motivational and instructional strategies, in order to favor self-efficacy and security in the adopted decisions, as well as refute myths and misconceptions. One of the strategies in this process is to promote health at different levels. At the lowest level, the focus is on changing individual behavior and disease management; at the intermediate level, it 
turns to interventions that have an impact on organizations and communities; and at the top level, is found in the information policies that affect the population ${ }^{(12)}$.

It is possible to conclude that the COVID-19 pandemic leaves a great legacy, especially regarding behavioral influence as the main risk factor for the spread of the disease. However, conscious adherence to these changes depends on individual, cultural characteristics, beliefs, location, norms and the perception of risk associated with illness.

In a practical way, the perception of behavior results in the ability to control the pandemic. In other words, when realizing that isolation and social distance reduce the risk of contagion of the disease, it increases the confidence and security in the control of contamination by coronavirus.

\section{FINAL CONSIDERATIONS}

It is believed that the health paradigm will change worldwide, which will be totally dependent on the behavior and heterogeneity of the belief system related to COVID-19. When reflecting on this model, it is reinforced that individual perceptions about risks and severity weigh modifiable risk factors, benefits and barriers, which are essential in the health and disease process.

Still, it is added that the transmission of false news and information, without scientific nature, results in the failure of the pandemic management and directly interferes in the low adoption of preventive behaviors. Thus, the hesitation to quickly provide adequate and secure information on the number of cases and the real effectiveness of prevention measures does not necessarily promote, in all, the same risk perception.

Furthermore, distorted and stigmatized views generate low adherence to prevention behaviors. Therefore, it is absolutely necessary to understand the importance of continuous health education processes based on secure information and integrated scientific evidence, in addition to tools aimed at responsible and engaged human behavior. This allows decision-making that can encourage the construction of critical and reflective thinking in the population, reducing the spread and consequences of the new coronavirus.

\section{REFERENCES}

1. Jieyun Z, Pan Ji, Jielong P, Zhimei Z, Hongyuan L, Cuiying H, et al. Clinical characteristics of COVID-19: a meta-analysis. J Med Virol[Internet]. 2020 [cited 2020 May 20];94:91-5. Available from: https://onlinelibrary.wiley.com/doi/abs/10.1002/jmv.25884

2. World Health Organization (WHO). Coronavirus disease (COVID-19) pandemic: numbers at a glance[Internet]. 2020[cited 2020 May 20]. Available from: https://www.who.int/emergencies/diseases/novel-coronavirus-2019.

3. Ministério da Saúde (BR). Painel de casos de doença pelo coronavírus 19 (COVID-19) NO Brasil pelo Ministério da Saúde [Internet]. 2020[cited 2020 May 20]. Available from: https://covid.saude.gov.br/

4. Costa MF. Modelo de crença em saúde para determinantes de risco para contaminação por coronavírus. Rev Saúde Pública. 2020;54:47. doi: $10.11606 / \mathrm{s} 1518-8787.2020054002494$

5. Lima DLF, Dias AA, Rabelo RS, Cruz IDD, Costa SC, Nigri FMN, et al. COVID-19 no estado do Ceará, Brasil: comportamentos e crenças na chegada da pandemia. Ciên Saúde Coletiva [Internet]. 2020 [cited 2020 May 13];25:1575-86. Available from: https://www.scielosp.org/ article/csc/2020.v25n5/1575-1586/pt/

6. Xiao Y, Torok ME. Taking the right measures to control COVID-19. Lancet Infect Dis. 2020;20(5):523-4. doi: 10.1016/S1473-3099(20)30152-3

7. Rosenstock IM. The health belief model and preventive health behavior. Health Educ Monogr. 1974;2(4):354-86. Available from: https:// journals.sagepub.com/doi/abs/10.1177/109019817400200405

8. Brooks SK, Webster RK, Smith LE, Woodland L, Wessely S, Greenberg N, et al. The psychological impact of quarantine and how to reduce it: rapid review of the evidence. Lancet. 2020;395(102227):912-20. doi: 10.1016/S0140-6736(20)30460-8

9. Rafael RDMR, Neto M, Carvalho MMB, David HMSL, Acioli S, Araujo Faria MG. Epidemiologia, políticas públicas e pandemia de Covid-19: 0 que esperar no Brasil? Rev Enferm UERJ. 2020;28:49570. doi: 10.12957/reuerj.2020.49570

10. Atchison CJ, Bowman L, Vrinten C, Redd R, Pristera P, Eaton JW, Ward H. Perceptions and behavioural responses of the general public during the COVID-19 pandemic: a cross-sectional survey of UK Adults. MedRxiv. 2020. doi: 10.1101/2020.04.01.20050039

11. Bezerra A, Silva CEM, Soares F, Silva JAM. Fatores associados ao comportamento da população durante o isolamento social na pandemia de COVID-19. Ciên Saúde Coletiva. 2020;25(1): 2411-21. doi: 10.1590/1413-81232020256.1.10792020

12. Pennycook G, McPhetres J, Zhang Y, Lu JG, Rand DG. Fighting COVID-19 misinformation on social media: Experimental evidence for a scalable accuracy-nudge intervention. Psychol Sci. 2020;31(7):770-80. doi: 10.1177/0956797620939054 
